\title{
PSYCHE
}

VOL. XVIII.

FEBRUARY, 1911.

No. 1

\section{ON THE HOMOLOGIES AND MECHANISM OF THE MOUTH-PARTS OF HEMIPTERA.}

\author{
By F. Mutr and J. C. Kershaw,
}

Mossman, North Queensland.

PART I. The Homologies of the Mouth-parts.

The morphology of the head of Hemiptera has received sereral interpretations, some writers maintaining that there are no traces of mandibular structure, while others consider the outer pair of setæ as the mandibles, and the inner pair as the maxillæ, but most writers agree in considering that the setæ are sunk into the head-capsule. One of the authors in a former paper ${ }^{1}$ endearored to show that in Pyrops candelaria the mandibles were present and articulated in their normal position, viz., to the head-capsule, between the clypeus and the maxillæ, and that the maxillæ are present in the form of two large plates in intimate contact with the maxillary setæ. In the present paper the authors have endeavored to show that the same interpretation holds good for other Hemiptera, and also that the frons, clypeus and labrum of many systematists are, in many families, respectively the clypeus, labrum and epipharynx.

If the head of a Cicada (Fig. 1) be softened in water or caustic potash the groove $(\mathrm{ms})$ along each side of the anterior part of the head will prove to be a distinct sutıre, whose edges are pressed closely together, but neither cemented nor joined by membrane. We will call this the "mandibular suture." At the posterior end of this suture are articulated, by a true ginglymus articulation, the mandibular setæ (art. man. s.). The dorsal surface between these two points will be the clypeus or clypeal region $(c l r$.). The position of the articulation of this seta enables us to homologize it

\footnotetext{
${ }^{1}$ A Memoir on the Anatomy and Life-History of the Homopterous Insect Pyrops candelaria. J. C. Kershaw. Zoöl. Jahrb. Abth. f. Anat.: XXIX, p. 105-124.
} 
with the mandible of mandibulate insects. The lateral edges of the clypeus are often turned down and produced into free plates $(c)$ projecting forward and fitting in between the labrum and the maxillary plates $(m x p)$. The separation of the clypeus and the labrum is often difficult to recognize in an external view, but internally the anterior part of the pharynx is fastened to the anterior part of the elypeal region by two chitinous struts or pillars; beyond this point the walls of the pharynx separate into the epipharynx and hypopharynx; the pharyngeal museles are attached to the wall of the elypeus. The division between the labrum and the epipharynx is often very obscure, and it may be more convenient to use the compound word "labrum-epipharynx," as is done in the Diptera. The latero-ventral coverings of the mouth are formed by two plates $(m x p)$, the anterior edges meeting along the ventro-medial line, thus elosing the mouth below and beyond the hypopharynx and syringe. The maxillary setæ pass through the membrane (hypodermis) at the base of the inner side, and the protractor muscles run forward and attach themselves to the walls, of these plates. We homologize these plates as the maxilli of mandibulate insects, and the setæe as maxillary setæ. Judging by Prof. Smith's study of the development of the palpifers in many insects, it is probable that the maxillary setæ in this order and in Thysanoptera are also developments of the palpifers. In the Homoptera the gular region is reduced to a minimum, in many cases being but a thin membrane connecting the labium with the occipital region; this causes the deflection of the head. The oceipital foramen is very large. Posterior to the antenne the head-capsule is often developed into a "frontal" or antennal ridge $(f r)$; this plays but a small part in the Homoptera, but in the Heteroptera it is large, and greatly modifies the shape of the head.

In many of the Hemiptera (i. e., Siphanta, Fig. 5) the mandibular setre (man.s.) are broad and bent a little beyond the base, protractor and retractor muscles proceeding to the head-capsule. In such forms their homology to mandibles is clear, but in other Hemiptera, especially among the Heteroptera, the tendon of the retractor muscle is greatly developed, and appears as the basal part of the setæ proceeding to the back of the head, the bent true basal portion being greatly reduced and specialized; in such 
forms it is hard to homologize them with mandibles without some knowledge of the more generalized forms.

The Cercopid head (Fig. 2) is similar to the Cicada. The clypeus $(\mathrm{clr})$ is large; the mandibular sutures $(\mathrm{ms})$ run half way along its sides; the frontal ridges $(f r)$ are drawn out over the antenna, and along the basal sides of the clypeus, and the gula is greatly reduced. The mouth parts of the Tetigonids are easily homologized with these.

In the Membracids (Fig. 3) all the same parts can be plainly seen. The clypeus (clr) is reduced somewhat basally; the mandibular sutures $(\mathrm{ms})$ approach nearer to the antennæ; the frontal ridges $(f r)$ are well developed, and the gula is greatly reduced.

Among the Derbids (Fig. 4) and Siphantas (Fig. 5) the head is drawn out anteriorly; the clypeus $(c l r)$ has its lateral parts $(c)$ long and the mandibular sutures $(m s)$ ruming back to near the base of the clypeus. In some species the eyes are comparatively small and the genæ large (Fig. 5, ge), in others the eyes are large and the genæ much reduced (Fig. 4, ge). The frontal ridges are very little dereloped in these families.

It is easy to homologize the head parts of most other families of Homoptera with the families quoted above, but the Heteroptera are more difficult. This is greatly on account of the gular region being much more largely developed, thus prerenting the deflection of the head and throwing the whole of the rentral and lateral parts of the head forward. The frontal ridges are greatly dereloped, and alter the shape of the head, but this is also the case among the Psyllids.

Among the Lygæids (Fig. 6) the homologies of the head are clear. The clypeus $(c l r)$ with its lateral pieces $(c)$ are well developed; the mandibular sutures ( $m s$ ) run to near the antennx; the maxillary plates $(m x p)$, owing to the development of the gula and the anterior position of the labium, are greatly shortened. The frontal ridges are absent, unless the raised rim around the antennæ represents them.

Among the Pentatomids the frontal ridges play a conspicuous part. In Cyrtocoris they are large, project forward, and divaricate like horns. In Tessaratoma (Fig. 7) they are flattish, project forward, and meet along the central line $(c . f r)$, the clypeus being deflexed near its base, and passes between them (c. clr) The 
head-capsule behind the eyes is well developed, the gula large. the maxillary plates $\left(\begin{array}{llll}a & \& & b & m x p\end{array}\right)$ reduced and the mandibular sutures $(a . m s)$ short and end near the antemnx.

In the Coreids (Fig. 8) we find a similar arrangement, but the inner edges of the frontal ridges do not meet together so closely and do not cover the base of the antennæ. The gular region is elongated.

In certain of the Pentatomids (Fig. 9) the clypeus (cl $r$ ) is deflexed near its junction with the labrum, the frontal ridges ( $f r$ ) lie alongside of, but do not fuse with it. The clypeus thus becomes dorsal, and the maxillary plates are thrown forward. A similar arrangement takes place in the genus Coleotichus.

The Reduviid head (Fig. 10) is the most difficult of all the Hemiptera to homologize, on account of the distortion that has taken place through its elongation, the ventral part having developed out of all proportion to the dorsal surface.

In Pristhesancus (Fig. 10) it is impossible to recognize the clypeal region from an external riew, but upon dissection one finds that the pharynx is attached to the head by its lateral struts at a point slightly anterior to the base of the antennæ (b.st), and the pharyngeal muscles are attached to the medio-dorsal surface behind these points. By homology with other Hemipterous heads this must be the clypeal region (c. clr.). This form of head could be brought about by two processes, firstly by amalgamation of the sides of the frontal ridges with the sides of the clypeus in such a head as Figure 9, and the forward movement of the lateral parts of the head, along with the elongation of the gula; or, secondly, the frontal ridges could have moved forward with the lateral and rentral parts of the head, and become abortive, leaving the clypeus surrounded by and fused with the headcapsule. In allied species there is a small prominence behind each antenna which appears to be the remains of the frontal ridges, thus indicating that the latter process is the more likely one. The labrum and epipharynx $(l b e)$, the maxillary plates $(m x p)$ and the mandibular sutures $(m s)$ and the articulation of the mandibular setæ (art. man. s.) are normal and easily homologized with other Hemipterous heads. The head behind the eyes is greatly elongated.

The nearest homology to the Hemipterous mouth parts is 
found in the Thysanoptera, where the maxillæ form long, subtriangular plates which, together with the labrum, form a short tube through which the setæ pass. 'The paired setæe are mandibular, and the unpaired seta pertains to the left maxillary, the right being absent. ${ }^{2}$ An analogy, if not homology, is to be found among the Myriapods in the family Polyzoniidæa ${ }^{3}$, where the mouth is adapted for sucking. Here the upper lip is produced into a narrow snout, the lateral edges being turned down to form a semi-tube; the protomalæ are drawn out anteriorly into long slender setx, with slightly spoon-shaped tips, set round its edges with fine teeth, the basal part being stouter, somewhat triangular, and articulated in the normal position (viz., near the base of the dentomalæ). The dentomalæ form a thin plate, rounded at its base, and drawn out thin anteriorly, which fits exactly against the edges of the elongated upper lip, entirely covering the protomalæ, thus making them internal organs.

\section{PART II. The Mechanism of the Mouth-parts.}

The membranous oesophagus (Figs. 11 \& 12 oe) passes between the brain $(b r)$ and the sub-øsophagal ganglion $(s g)$, and then merges in the chitinous pharynx $(p h)$. The pharynx is of the usual double U-shape in transverse section, the dorsal plate being thin and flexible, and capable of retraction from the thick and chitinous ventral plate by the powerful pharyngeal muscles $(\mathrm{phm})$, thus creating a vacuum into which the liquid food flows; the dorsal plate then falls back against the ventral plate by the natural elasticity of the pharynx. The whole structure constitutes the pharyngeal pump. The anterior portion of the dorsal plate $(d p h)$ of the pharynx continues along the under side of the labrum $(l e)$ and forms the epipharynx $(e)$. The ventral plate of the pharynx $(v p h)$ continues forward and forms the spoon-shaped and acute hypopharynx (hyp). At the anterior end of the pharynx the lateral edges of the ventral plate emit two struts $(s t)$, one each side, which diverge laterally and upwards, and fuse with the anterior sides of the clypeal region $\left(c / r^{\circ}\right)$. These struts form the

\footnotetext{
2See Note A.
}

${ }^{3}$ The description of this mouth is taken from a species very common in rotten wood in the Island of Ceram. 
main support of the pharynx. Just below these pharyngeal struts the pharynx emits two other struts $\left(t s^{1}\right)$, one each side, whieh proceed almost horizontally and posteriorly and fork, sending a strut $\left(t s^{2}\right)$ anteriorly to the base of the salivary-pump or syringe $(s p)$. This strut again forks and sends a strut $\left(t s^{3}\right)$ anteriorly to the base of the labium $(b l)$. Posteriorly (beyond the first forking) the struts become broad and thin plates following the sides of the pharynx, and attached to its outer walls by tissue. The plates in transverse section are roughly $V^{\prime}$-shaped (Fig. 19d) and connected together by tissue; they enelose and protect the setr. From the posterior end of the chitinous pharynx, where the plates become broadest, they rapidly narrow to mere tendons, which extend right to the occipital foramen, where the tips of the two tendons broaden slightly, and attach to the oceiput near the attachment of the retractor museles of the setx. In more generalized forms, such as the Cieada, the posterior ends of these seta-guides are connected by a transverse piece whieh gives off two branches that are attached to the dorso-posterior part of the head-capsule. This appears to indicate that the whole structure is a modification of the tentorium to form a guide or protection to the setre, and give support to the floor of the mouth for the working of the salivary syringe. We therefore eall this arrangement of struts, plates and tendons the tentorial structure $(t s)$.

The syringe, or salivary pump $(s p)$, lies beneath the anterior part of the pharynx and opens on the basal part of the labium $(b l)$, beneath the hypopharynx. 'The body' of the syringe is cupshaped, and highly chitinous, with an inverted top, thinner and more flexible, which forms a plunger. From the center of the plunger rises a chitinous tendon or phunger-rod, around whieh are attached the powerful retraetor museles $(\mathrm{spm})$. These muscles divide slightly posteriorly and form two branches which attach to the base of the oceiput beneath the occipital foramen. The two salivary duets $(s d)$, after entering the head, lie on the floor of the head-capsule in the space between the two branches of the syringe muscles, and join in a very short common duct just before entering the syringe near the valve $(v)$. This valve is formed by a membraneous fold of the syringe wall, which eovers a shallow recess made by a bulge in the wall where the common duct enters. 
The orifice of the syringe tube opens through the base of the labium, and is covered by a small chitinous tongue $(p t)$, which lies just beneath the hypopharynx. The plunger being retracted by the muscles $(s p m)$ draws the saliva from the ducts $(s d)$ into the syringe barrel. On the relaxation of the muscles, the natural elasticity of the plunger performs the return stroke, closing the valve $(v)$ and forcing the saliva past the tongue $(p t)$ on the base of the labium.

The labium is four-jointed and sub-cylindrical in cross-section, with a longitudinal groove running down its dorsal surface. Beyond the distal end of the labrum-epipharynx (le) the edges of the groove meet together, and so form a trough in which the setæ lie. Strong muscles between the dorsal and ventral walls of the labium enable the edges of the trough to be parted so as to set the setæ free. The ventral wall (Fig. 13, vwl) is formed by very thick chitin, perforated by numerous pores; the dorsal wall $(d w l)$ is thin and flexible. Two large tracheæ $(t r)$, and two nerve-cords $(n)$ pass down to the tip of the rostrum. The rostrum is retracted and drawn up to the underside of the head-into its normal position at rest--by the retractor muscles (Fig. 11, rm) attached to the greatly reduced first ventral sclerite $\left(v b l^{4}\right)$; it is extended by the muscles $(\mathrm{em})$ attached to the second dorsal sclerite. Longitudinal muscles down the interior of the rostrum actuate the several joints thereof; the last joint, or tip, is especially mobile, and can be deflected laterally to either side.

Almost on the mandibular suture (Fig. 10, ms), but slightly below and at the posterior end thereof, the mandibles are connected to the genæ by a ginglymus articulation (Fig. 12, $g$ and Fig. 10, art. man. s), consisting of a small rod and triangular plate, the latter hinging directly to the gena. The protractor muscles $\left(\mathrm{pm}^{1}\right)$ of the mandibles (man. $s^{1}$., Figs. 12 and 14) attach to the clypeal region between the bases of the antemnæ, and at the other end at one arm of the triangular base of the mandible (Fig. 14, tbm). A membranous sleeve $(\mathrm{msl})$, arising from near the articulation of the triangular base of the mandible, encloses the mandibular seta, and forms the air-tight joint; at the anterior end the sleeve (part of hypodermis) opens near the base of the maxillary plate. Behind the ginglymus the setæ narrow to mere

'This is the free part of basal labial joint; the rest is fused with gular region. 
tendons, at the posterior ends of which are the retractor muscles (shown broken off in Fig. 12b), attaching to the occiput on each side of the occipital foramen.

The muscles of the maxillary setæe are much more powerful than the mandibular muscles. The protractor muscles (Fig. 19b, $\mathrm{pm} \boldsymbol{\beta}$ ) attach to the maxillary plate (Fig. 10, mxp). In the drawing they are shown slightly curved, to avoid confusion with other parts, but in reality they are practically straight. The retractor muscles attach to the occiput on each side of the occipital foramen. Passing forward between the plates of the tentorial structure $(t s)$, (where the mandibular setxe lie on a slightly higher plane than the maxillary) the pairs of setæ on either side of the pharynx approach closer together and pass between the struts (Fig. 11, $t s^{1}$ and $t s^{2}$ ) from the pharynx and the base of the labium, run alongside and partly beneath the hypopharynx, and descend over the base of the labium $(b l)$ into the rostrum. Soon after entering the rostrum, the maxillary setæ close together and interlock (Fig. 13 max s), forming an air-tight tube. The tips of the maxillary setre are acute and smooth. The tips of the mandibular setæe are flattened and acute, and numcrously and minutely barbed on the outer sides, the barbs pointing backwards. The tips of both pairs of setxe are practically without curve. The mandibular setæe are quite free from the maxillar setæ, though they lie close on each side of the former in the rostrum.

That the maxillary setæ form an air-tight tube can easily be seen under a fairly high power, when liquid food and bubbles of air can be traversed from end to end of the tube by pressing with a needle. The maxillary setx or sucking-tube can be protruded far beyond the tip of the rostrum, whilst the mandibular setæe can be protruded only slightly. The latter are used to pierce the prey, and retain it in position by means of their barbed tips, whilst the maxillary setæe forming the sucking-tube are probed and extended into every part of the body where there are any juices. It seems probable, also, that the sucking-tube is used to conduct the poisonous saliva from the syringe into the wound madein the animal attacked. On attacking any animal the bug probably slightly protrudes the tips of the setæ and contracts the muscles at the end of the rostrum, the latter thus closing on and holding the tips of the setæ firmly. The animal is then pierced and securely 
held by the barbed tips of the mandibular setæ. It seems highly improbable that long slender rods like the setæ could pierce a chitinous insect without some support near their tips. Carnivorous bugs almost invariably suck their prey whilst it is suspended from the tip of the rostrum, the bug meanwhile resting head downwards; they often retain their hold on the prey and continue to suck out its contents whilst the labium is withdrawn against the ventral plates of the head and thorax-its usual position when at rest. This feat would be impossible unless the prey was held by the barbed tips of the mandibular setre, whilst the maxillary setæ were used to search the interior of the body for juices.

Note A. (Fig. 14)

This interpretation differs both from Uzel's and Garman's, and is founded upon observations of a head of one of the Tubulifera common in the flower of the sugar cane in the Mossman district (North Queensland). We figure this head and give the following short description to prove our homology.

The head-capsule is of the usual Thrips type, being deflexed and inflexed, the mouth-parts being brought between the front legs, as in Homoptera. The anterior edge of the head-capsule (the oral margin) is strengthened by a thick rim of chitin $(r)$. From this rim arise two short pillars $(k)$, one on each side, above the maxilla, which proceed backward into, and sub-parallel with the wall of, the head-capsule. At the distal end of these pillars are articulated, by at perfect ball and socket joint (Fig. 14, z), the mandibular setæ. Beyond these pillars are two stout conical pegs arising from the head-capsule, evidently for the attachment of muscles. The clypeus $(c / r)$ is well developed and slightly asymmetrical, the left basal corner being emarginate. The labrum $(l b)$ is small, with its lateral edges bent round ventrally to form a semi-tube. The right maxilla is formed by a sub-triangular plate (Fig. 14a. mxp), the palpus arising from a membranous part of the center; the left maxilla is asymmetrical, a membrane separating the sub-triangular distal part, bearing the palp (Fig. $14 \mathrm{y}$. $m x p . b$.), from the rounded basal part bearing the seta (Fig. 14 $y, \operatorname{mxp} . a$. and max. s.). This basal part is capable of movement apart from the distal part, and carries the seta along with it. The anterior edges of the maxillæ meet in the medial line beneath 
the labrum and help to form the tube beyond the pharynx through which the setæ pass. The labium is short, wide, and consists of three parts, a broad basal portion (mentum?), a second smaller part bearing the palpi (palpifer?), and a minute distal portion bearing two minute bodies (paraglossæ?). The pharynx is small, well developed, and situated below the clypeus, to which it is attached by lateral arms; the epipharynx and hypopharynx are indistinguishable. The base of the maxillary seta is short, the tip flat and acute, without barbs, and evidently only used for piercing. The mandibular setæe are slightly spatulate at the tips, and show no traces of groove under a 1-9 inch objective.

The paired setæ we consider as mandibular, homologus to those of Rhyncota, the part of the rim of the head-capsule to which they were articulated having grown inwards to form the mandibular pillars $(k)$. The unpaired seta arises from the left maxilla, and is part therof. The sub-triangular plates forming the maxillæ may be the palpifers, the other parts being reduced or lost. This interpretation was confirmed on another species of Tubulifera, but two species of Terebrantia differed, and showed an arrangement of mouth organs agreeing with Garman, viz:one mandibular seta on the left, and a pair of maxillary setæ. It is possible that this difference of mouth-parts will run through these two sub-orders.

Uzel's figure of Eolothrips fasciata does not bear out his suggestion that the unpaired seta is a development of the epipharynx, and in the species herein figured, there is no doubt of its maxillary origin.

June, 1910. 


\section{EXPLANATION OF PLATES.}

Fig. 1. Head of a Cicada

Fig. 2. Head of a Cercopid

Fig. 3. Head of a Membracid

Fig. 4. Head of a Derbid

Fig. 5. Head of a Pockillopterid

Fig. 6. Head of a Lygaeid.

Fig. 7. Head of a Pentatomid

Fig. 8. Head of a Coreid

Fig. 9. Head of a Pentatomid

Fig. 10

Head of a Reduviid

In these ten figures $\mathrm{a}=$ front view, $\mathrm{b}=$ side view, $\mathrm{c}=$ dorsal view.

Fig. 11

$a=$ Longitudinal median vertical section of anterior part of head.

$\mathrm{b}=$ View looking down on pharynx, etc.

$\mathrm{c}=$ View looking on side of pharynx, etc.

In $b$ and c, some of the parts are drawn slightly out of their natural position, to avoid hiding some of the structure.

Fig.12

$a=$ Longitudinal median vertical section of head.

$\mathrm{b}=$ Longitudinal horizontal section of head (slightly diagrammatic).

$c=$ Transverse section of head in front of antennæ, looking towards the occipital foramen.

$\mathrm{d}=$ Transverse section cut rather more posteriorly than $\mathrm{c}$.

Fig. 13

Transverse section of rostrum.

Fig. 14

Part of R. H. mandibular seta, much enlarged.

Head of a Thrips

Fig. 15

$a=$ front view.

$\mathrm{b}=$ side view

$\mathrm{y}=$ left maxilla enlarged

$z=$ articulation of seta with mandibular pillar 


\section{Lettering of Figures.}

\begin{tabular}{|c|c|c|c|}
\hline$a m$ & $=$ antennal muscle & $m x p$ & $=$ maxillary plate \\
\hline$a n$ & $=$ antenna & $n$ & $=$ nerve \\
\hline art. $m$ & man. s. = articulation of mandib- & $o c$ & $=$ ocellus \\
\hline & ular setæ & $o c c$ & $=$ occiput \\
\hline$b l$ & $=$ dorsal base of labium & $o e$ & $=$ œesophagus \\
\hline$b r$ & $=$ brain & ph & $=$ pharyn $x$ \\
\hline 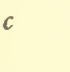 & $\begin{array}{l}=\underset{(\text { loræ })}{\text { clypeus, lateral edges of }} \\
\end{array}$ & phm & $\begin{array}{l}=\text { pharyngeal muscles } \\
=\text { protractor muscle of mandi- }\end{array}$ \\
\hline clr & $=$ clypeal region & & bular setæ \\
\hline $\begin{array}{l}d p h \\
d w l\end{array}$ & $\begin{array}{l}=\text { dorsal plate of pharynx } \\
=\text { dorsal wall of labium }\end{array}$ & $p m^{2}$ & $\begin{aligned}= & \text { protractor muscle of maxil- } \\
& \text { lary setæ }\end{aligned}$ \\
\hline$e$ & = epipharynx & $p t$ & = syringe-tongue \\
\hline$\dot{\varepsilon}$ & $=$ eye & pth & $=$ prothorax \\
\hline$e m$ & $=$ elevator muscle of labium & $r$ & $=$ thickened rim of head-capsule \\
\hline$f r$ & $=$ frontal ridge & $r m$ & $=$ retractor muscle of labium \\
\hline$g$ & $\begin{aligned}= & \text { ginglymus articulation of } \\
& \text { mandibular setæ }\end{aligned}$ & $\begin{array}{l}s \\
s d\end{array}$ & $\begin{array}{l}=\text { setæ } \\
=\text { salivary ducts }\end{array}$ \\
\hline$g e$ & $=$ genæ & $s g$ & $=$ sub-œsophageal ganglion \\
\hline$g u$ & $=$ gular region & $s p$ & $=$ salivary syringe \\
\hline$h c$ & $=$ head capsule & $s p m$ & $=$ salivary syringe muscles \\
\hline hyp & = hypopharynx & st & $=$ pharyngeal strut \\
\hline$k$ & $=$ mandibular pillar & $t$ & $=$ tendon \\
\hline$l a b$ & $=$ labium & $t b m$ & $=$ triangular base of mandible \\
\hline$l b$ & $=$ labrum & ts & $=$ tentorial structure \\
\hline le & $=$ labrum-epipharynx & $\operatorname{tr}$ & $=$ trachea \\
\hline$m$ & $=$ muscles & $v$ & $=$ valve of syringe \\
\hline $\operatorname{man}$ & $s_{.}=$mandibular setæ & $v b l$ & $=$ ventral base of labium \\
\hline $\max$. & $s_{.}=$maxillary setæ & $v p h$ & $=$ ventral plate of pharynx \\
\hline$m s$ & $=$ maxillary suture & vwl & $=$ ventral wall of labium \\
\hline
\end{tabular}


Psyche, 1911.

Vol. XViIi, Plate 1.
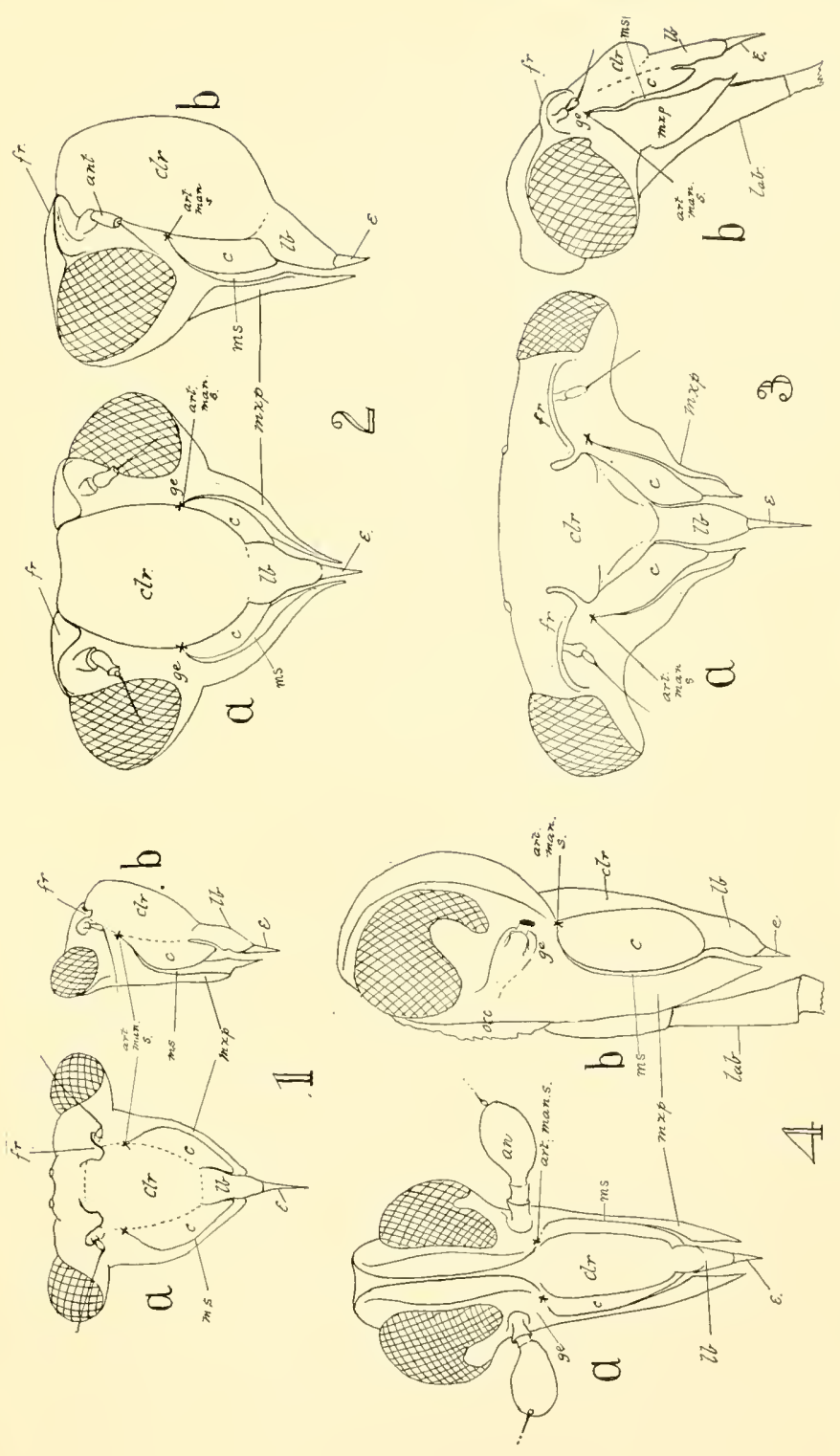

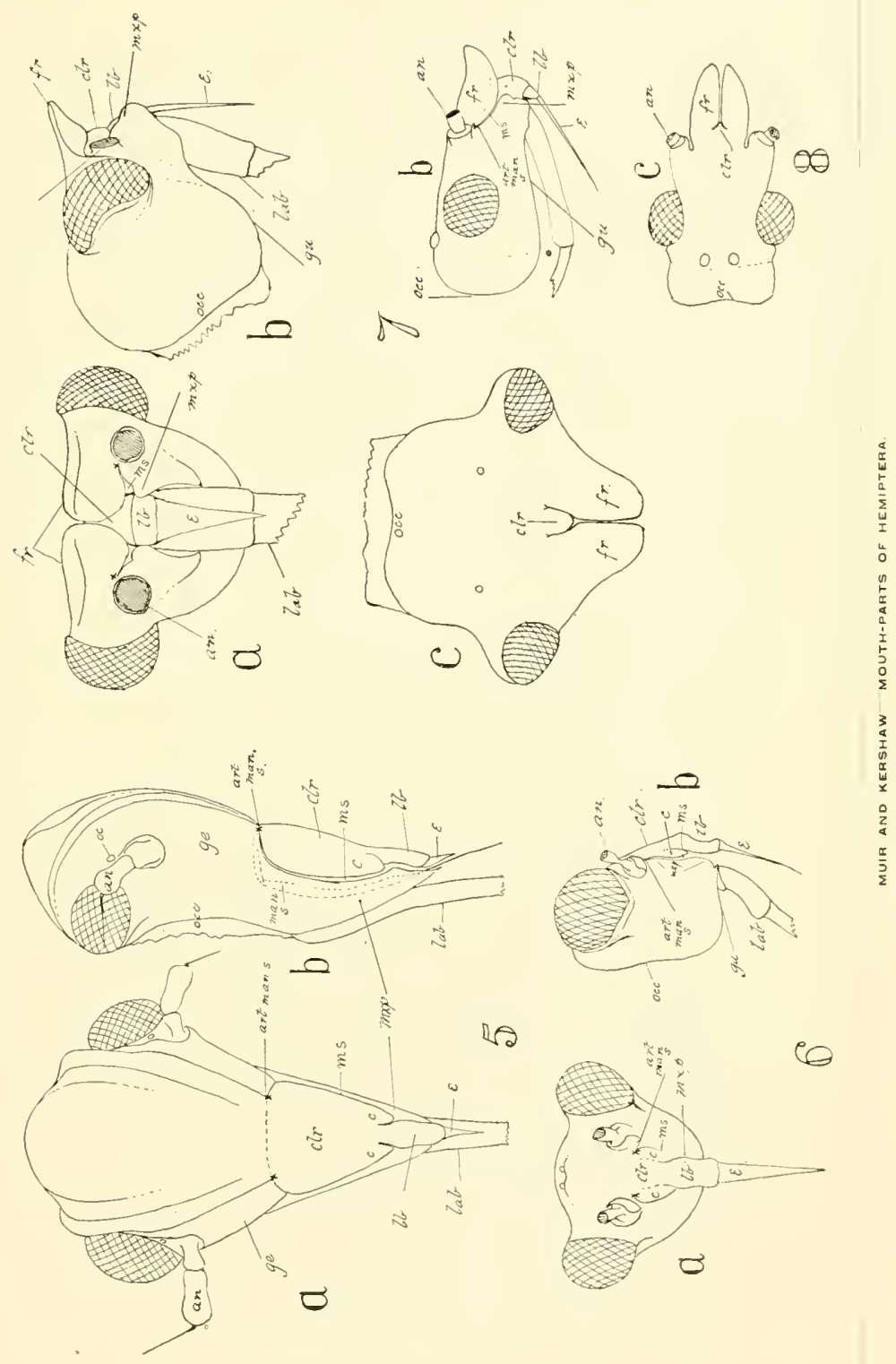

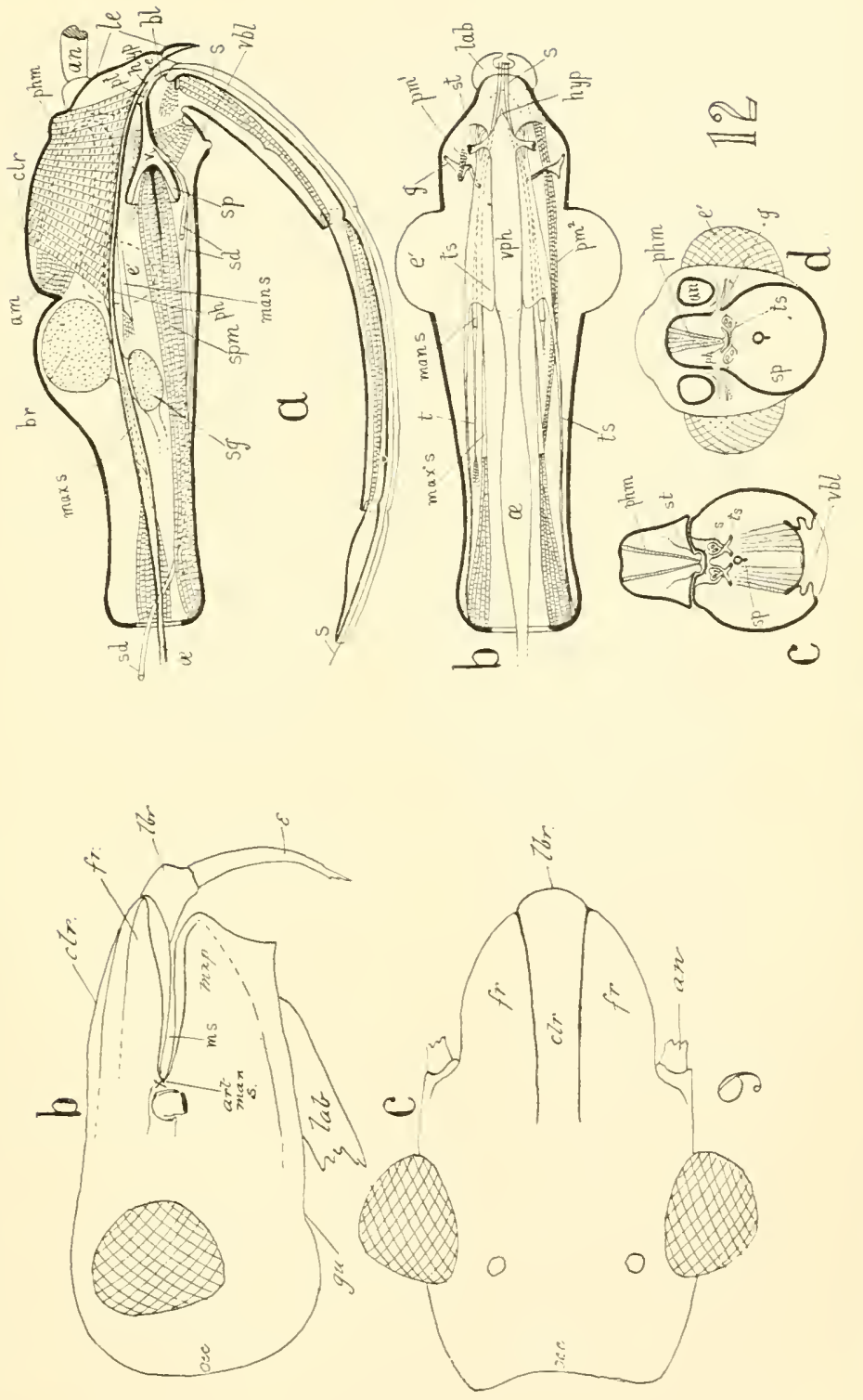

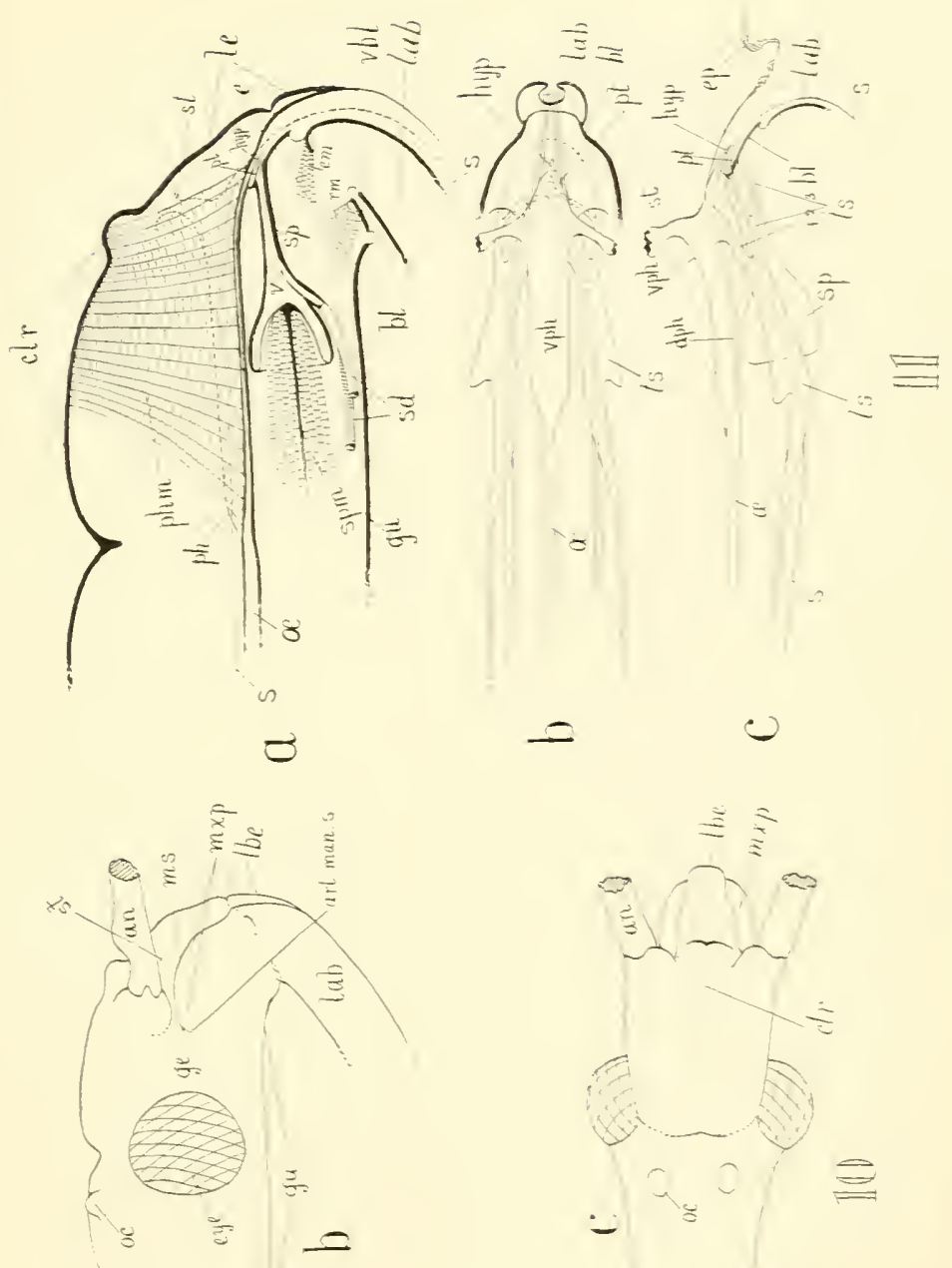


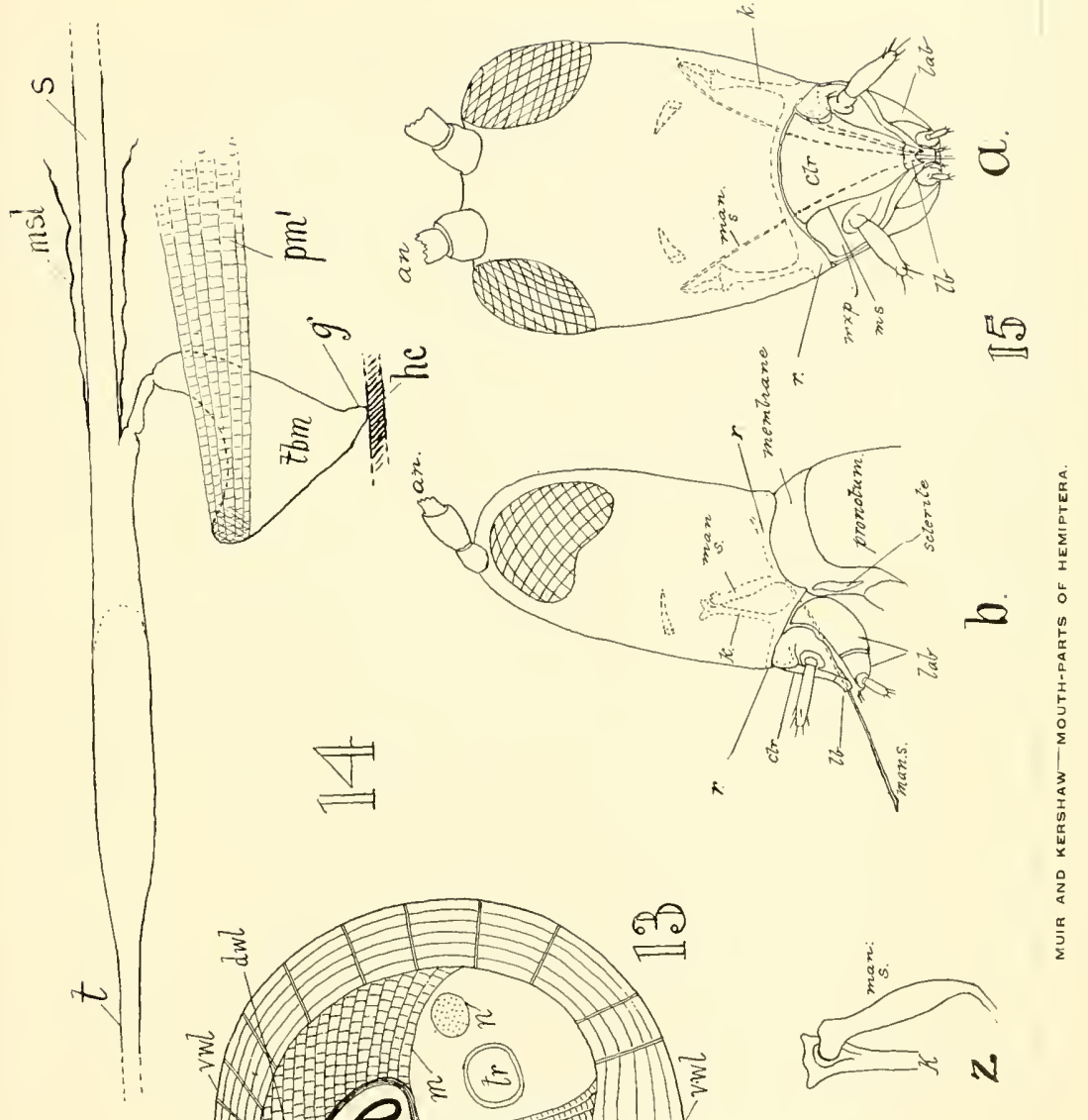



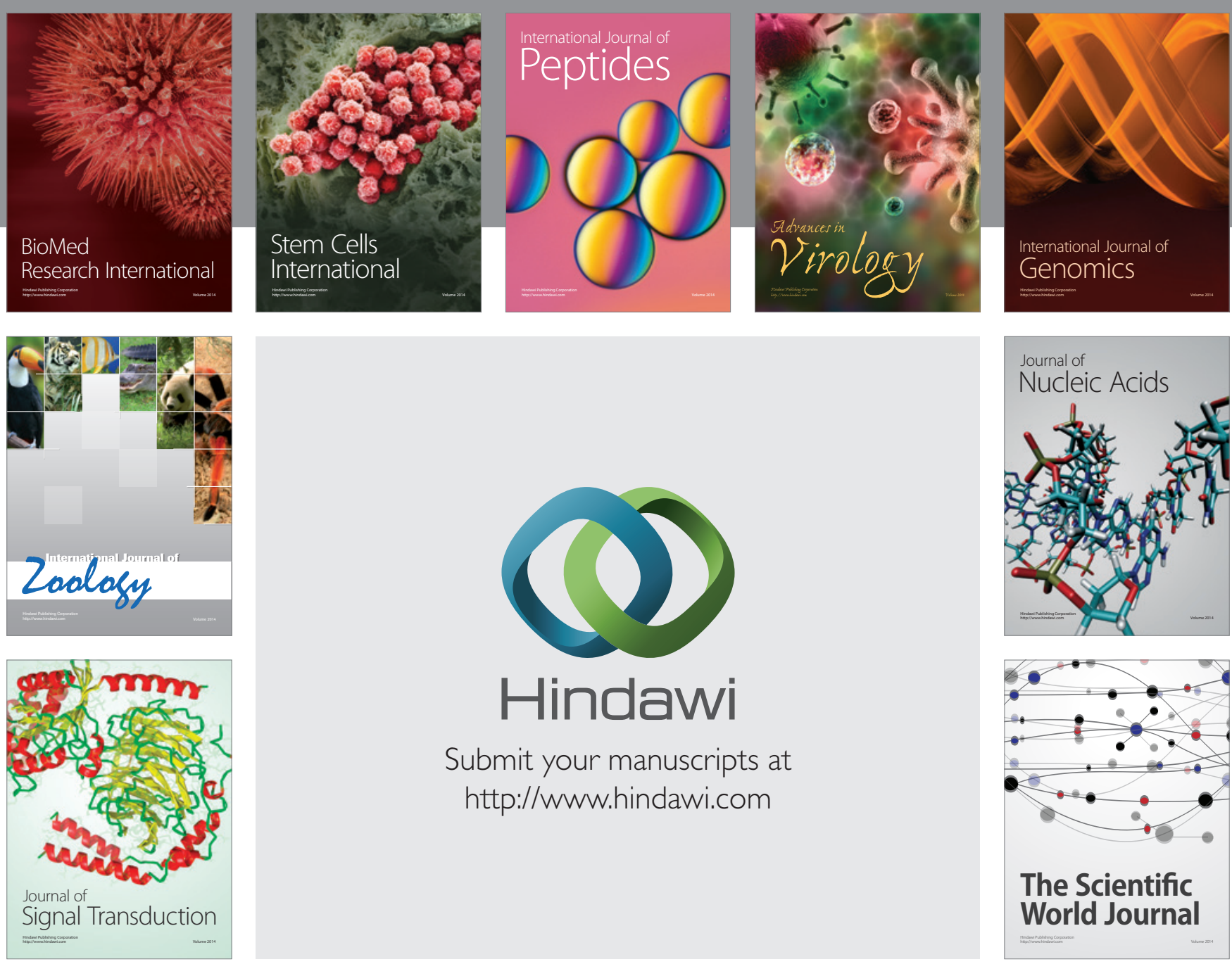

Submit your manuscripts at

http://www.hindawi.com
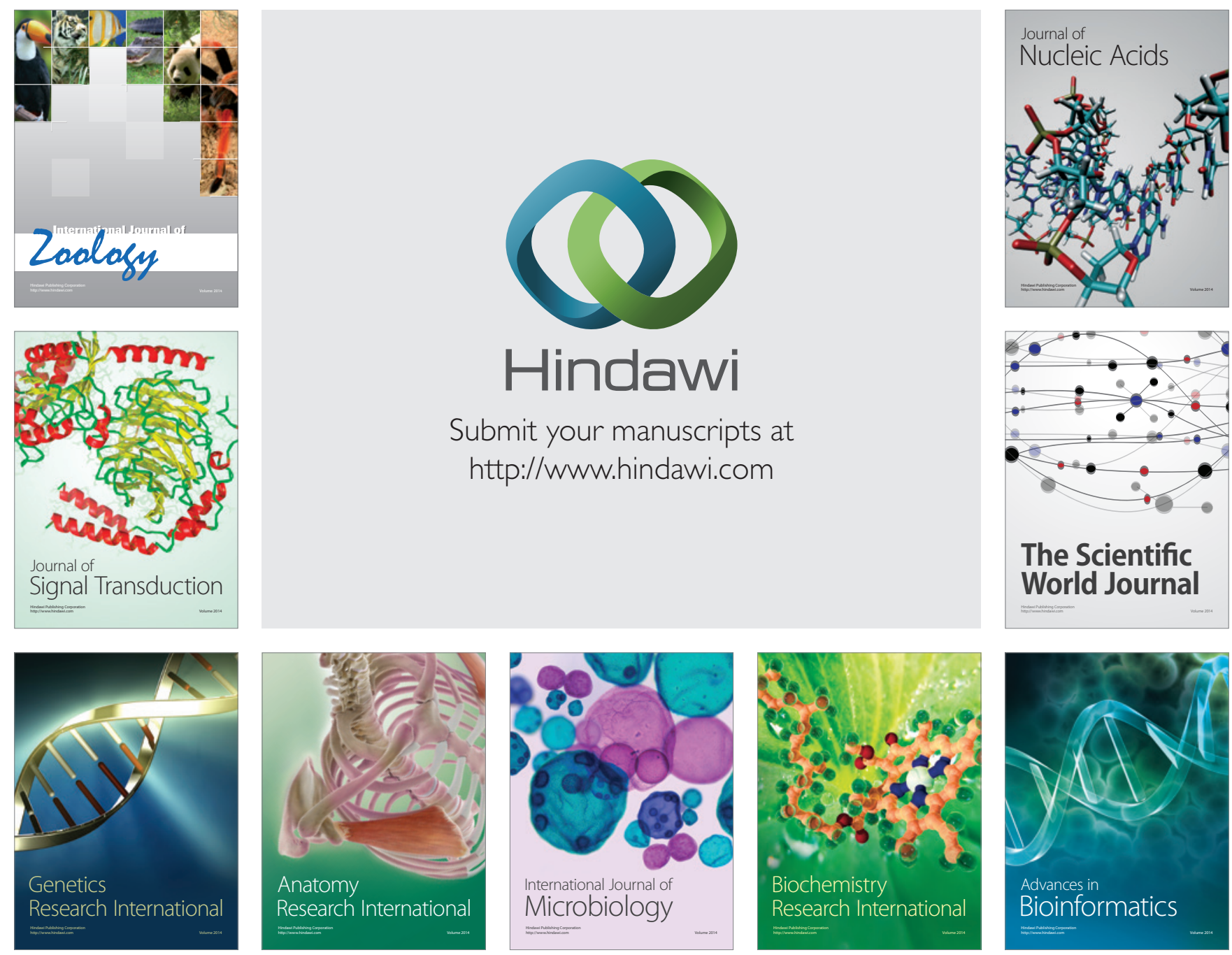

The Scientific World Journal
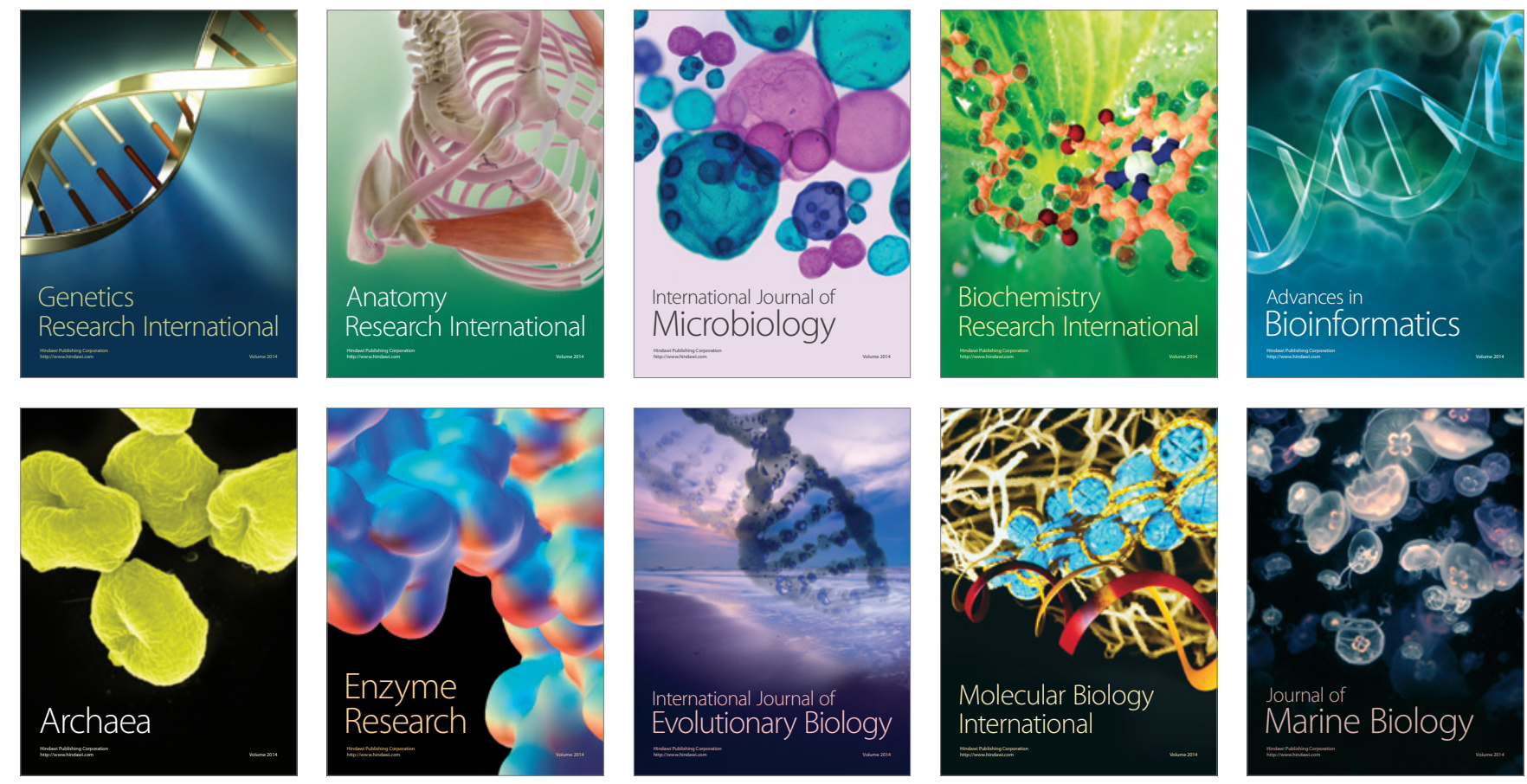